UDC 325.314

\title{
Energy Management and Event Detection in Heater System for Safety Application
}

\author{
V. M. Okhmak, ORCID 0000-0002-0621-3256 \\ National technical university of Ukraine "Igor Sikorsky Kyiv polytechnic institute" ROR 00syn5v21 \\ Kyiv, Ukraine
}

\begin{abstract}
In this article a method of analyzing and notification about an event in water heater is seen. Temperature, water flow and power consumption are main parameters for indication of alert data. For analyzing and the event detection data from the real-time measurement system is compared to the statistics from Influxdb, the temperature data was analyzed. The statistics in Influxdb is changing through the time by Moving Window function. The comparison of data from the realtime measurement system and Influxdb is performed with Gaussian distribution and applying of 3-sigma rule. Data which is indicated as not common and dangerous detects as the event. Information about the event detection is sent to the customer by email using Gmail service. As a result, the Gaussian distribution was built and the algorithm for the sending the message was written.
\end{abstract}

Keywords - Gaussian distribution; event detection; heater system; alert notification; Smart house; Smart Micro-Grid.

\section{INTRODUCTION}

New energy management systems have a lot of branches of improving and developing effective methods for energy using. One of the perspective of such methods is - informing about alert situations in the private residences which are occurred by power consumption and conterminal admeasurement in the house using water heater [1], [2]. In this article, the path that allows to inform the recipient's system in the residence about the alert event in heater system's data has been constructed, between measurement and client system. In order to perform the aim of indicating and informing client about an alert, the system of data-collection, data-statistic, data-analysis, event detection and recipient informing were constructed.

\section{DATA COLLECTION}

Measurement system of the water heater has different type of data. For this type of analysis. Only few data subjects which are the most interesting in alert indication are taken:

- Temperature

- Water flow

- Power line

Temperature data in heater system are taken through temperature sensors and sent to the database by Raspberry.Pi.

For the data collection of water heater in the house the copy of the measurement system presented by Raspberry.Pi was used [3] which give an opportunity to work with measurements in straight way in Influxdb. It is automatically decreased the delay in the processing time and gives better platform for future improving of an alarm system, possible additions to the data collection process and works which based on the data from heater system in real-time and state data. bases:

Data collection and analysis divided into two data-

- Data in real-time with which the analysis is made — Raspberry.Pi (Fig. 1)

- Data in which analysis is based, Influxdb [4] Influxdb (Fig. 1)

At the Fig. 1, you can see the visual diagram of approach of data collection after which there are two branches. First one is the data from measurement system, and the second one is Influxdb.

For data-base in which data for analysis based Influxdb is used. The energy management system should indicate overflow of energy usage and generation amount for the optional operation of databased on the measured energy amount [5]. For this purpose data from measurement system are saved to the state file which will be charged or discharge with data from measurement system. This process performed with Influxdb and window function for data in real-time. So, when the new data is coming to the document the last one will be deleted [6]. For a sample $x_{i}$ the mowing window function will be:

$$
W_{i}^{H, J}=\left\{x_{i-H}, \ldots, x_{i}, \ldots, x_{i+J}\right\},
$$

where $H$ and $J$ are non-negative integers specifying the number of samples to include before and after the sample $x_{i}[6]$, after all of necessary performances with data, the window is shifted by one sample to $x_{i+1}$. For the data from water heater shifting is each $5 \mathrm{sec}$ or 25 samples. 


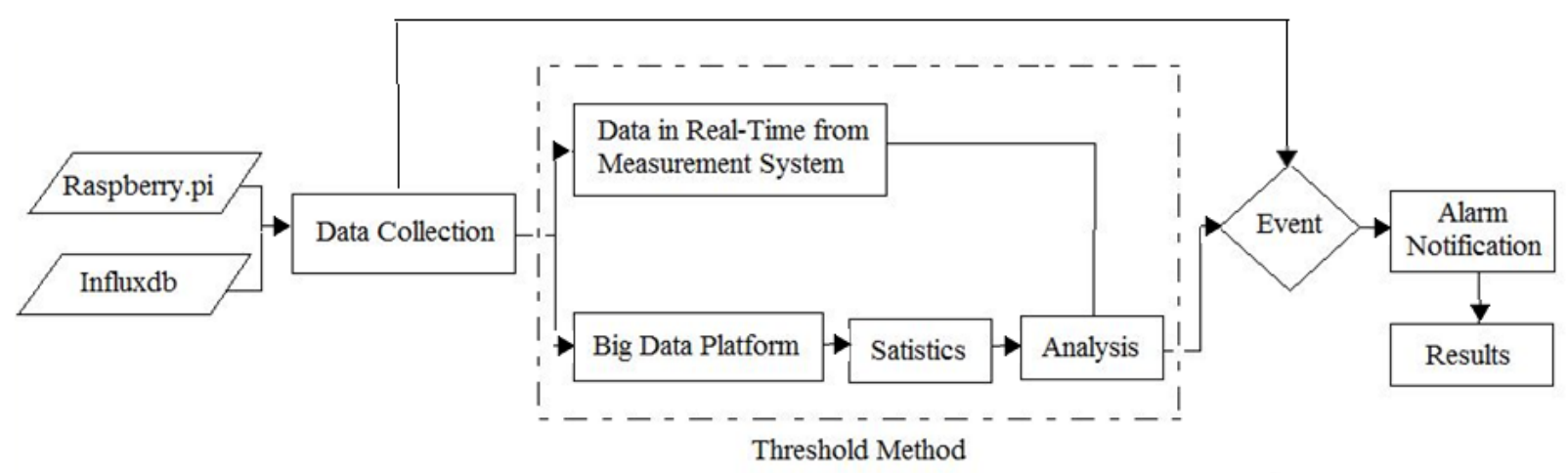

Fig. 1 The visual diagram of data processing from water heater with Threshold Method

The approach of dividing databases in two part prevents bugging and minimize processing time. Of course, it takes more space in the storage, but by adding window's property the space is approximately defined and are not increasing with time.

\section{DATA STATISTIC}

In this part the statistic of the data from measurement system is built. The method of finding state that might be an alarm is sufficiently the same to the Threshold method presented in [7], Fig. 1.

The statistic of data presented by Gaussian (normal) distribution. Gaussian distribution is widely used for natural phenomena and statistics, in order to describe repetitive pattern of data [8]. The Gaussian distribution is represented by the following expression:

$$
f(x)=\frac{1}{\sigma \sqrt{2 \pi}} e^{\frac{-(x-\mu)^{2}}{2 \sigma^{2}}}
$$

The main parameters of the function of Gaussian distribution are mean or expectation (2) and standard deviation (3):

$$
\begin{gathered}
\mu=\frac{1}{n} \sum_{i=1}^{i=n} x_{i}, \\
\sigma=\sqrt{\frac{1}{n} \sum_{i=1}^{i=n}\left(x_{i}-\mu\right)^{2}}
\end{gathered}
$$

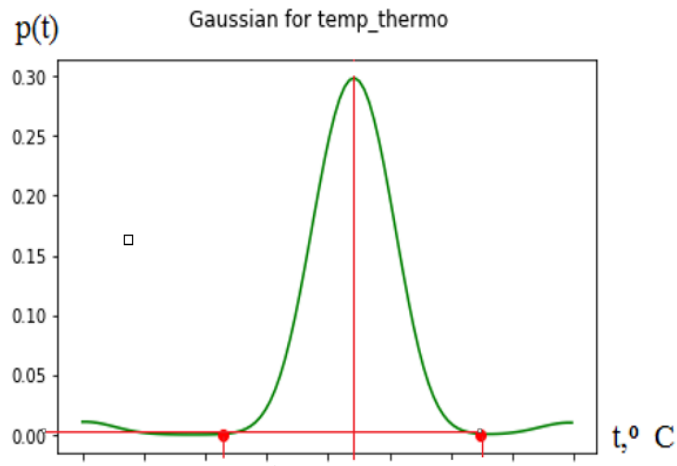

Fig. 2 Gaussian distribution of temperature`s data of heater system
The first step for preparing Gaussian distribution for the temperature is the indication of mean of the sequence of data. For this project it is moving average because the data set is changing through time. It is important because the mean indicates the results that meets with the biggest probability. After indication of mean, the next step is accomplishing the thresh value of data, in our case it is data which are out of 3sigma range. This approach is based on 3 sigma rule, detailed information about 3 sigma rule can be found in [9].

After applying formulas (3) and (4) to the large scale of data, statistics could be built. At the Fig. 2, you can see Gaussian distribution for data from Influxdb of water heater, $p(t)$ - the prohibition of temperature. Red point are indications of $+/-3$ sigma.

The indication of issue in the system or alert is simple: if data from measurement system is out of range of mean +/- 3 sigma of Influxdb, it will be indicated as unacceptable situation and automatically will be performed in the next step of alarm notification.

For water flow and power line the first point of alarm indication which equal to mean- 3 sigma are changed to 0 value, depending of nature of this data .Influxdb will help in building large range of available databased on measurement system.

\section{EVENT DETECTION}

Missing data, critical cold or hot temperature, big water or power consumption in line, all of this event could be in the real heater system. Control system and customer should be notified about this. At the Fig. 3, you can see how the information is indicated.

Event detection is performed trough block Analysis in visual diagram Fig. 3. The data in real-time is compared with data from statistic in Influxdb [10] if any of incoming data are indicated as an event the information going to be computed ahead in the next step.

System sends an email to recipients with large description about an event. For that process Gmail service was chosen. It is large system with good protection and wide range of improving this path in the future. As an example system could be improved by adding notification to the service of the house, and instantly removed. 


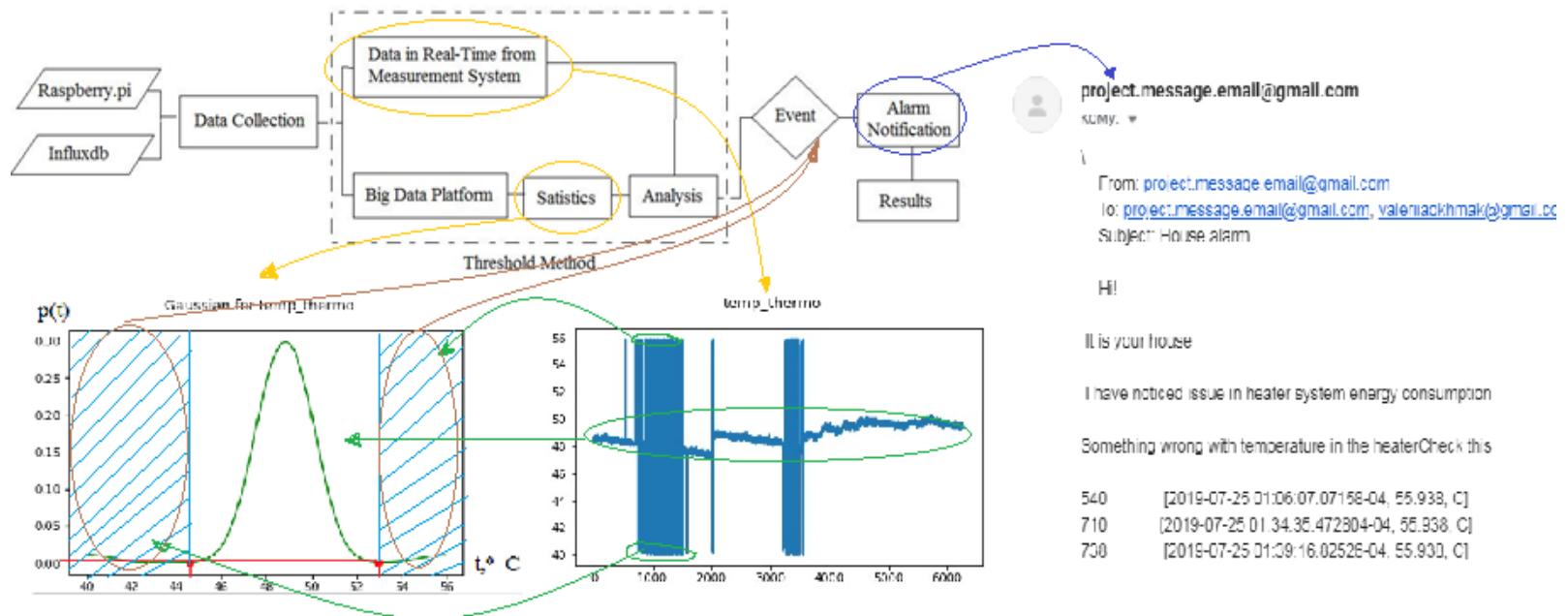

Fig. 3 Visual diagram of event detection and notification

\section{CONCLUSION \& RESULTS}

Simplification of house routine can bring improving to any conformation. The Energy management system reads, saves, makes statistic and analysis on saved data, indicate alarm and notify system about that. Following by code it sends message to the recipient with all needed data and information about system. The result was that the message has been sent.

\section{REFERENCES}

[1] I. Colak, H. Wilkening, G. Fulli, J. Vasiljevska, F. Issi, and O. Kaplan, "Analysing the efficient use of energy in a small smart grid system," in 2012 International Conference on Renewable Energy Research and Applications (ICRERA), Nov. 2012, pp. 1-4, DOI: $\underline{10.1109 / \text { ICRERA.2012.6477410. }}$.

[2] S. Guzhov and A. Krolin, "Use of big data technologies for the implementation of energy-saving measures and renewable energy sources in buildings," in 2018 Renewable Energies, Power Systems \& Green Inclusive Economy (REPS-GIE), Apr. 2018, pp. 1-5, DOI: $\underline{10.1109 / R E P S G I E .2018 .8488861}$

[3] N. S. Yamanoor and S. Yamanoor, "High quality, low cost education with the Raspberry Pi," in 2017 IEEE Global Humanitarian Technology Conference (GHTC), Oct. 2017, pp. 1-5, DOI: $10.1109 / \mathrm{GHTC} .2017 .8239274$.

\section{Надійшла до редакції 15 березня 2020 року}

[4] Z. Wang, B. WU, D. BAI, and J. QIN, "Distributed Big Data Mining Platform for Smart Grid," in 2018 IEEE International Conference on Big Data (Big Data), Dec. 2018, pp. 2345-2354, DOI: $\underline{10.1109 / B i g D a t a .2018 .8622163}$.

[5] T.-Y. Ku, W.-K. Park, and H. Choi, "Self-learning mechanism for prediction of energy consumption and generation," in 2018 20th International Conference on Advanced Communication Technology (ICACT), Feb. 2018, pp. 359-362,

DOI: $\underline{10.23919 / \text { ICACT.2018.8323756. }}$.

[6] W.-M. Wu, F.-T. Cheng, and F.-W. Kong, "Dynamic-MovingWindow Scheme for Virtual-Metrology Model Refreshing," IEEE Trans. Semicond. Manuf., vol. 25, no. 2, pp. 238-246, May 2012, DOI: $10.1109 /$ TSM.2012.2183398.

[7] O. S. da Penha and E. F. Nakamura, "Fusing light and temperature data for fire detection," in The IEEE symposium on Computers and Communications, Jun. 2010, pp. 107-112,

DOI: $\underline{10.1109 / \text { ISCC. } 2010.5546519}$.

[8] V. P. Jilkov, J. R. Katkuri, and H. K. Nandiraju, "Design of Bayesian signal detectors using Gaussian-mixture models," in 2010 42nd Southeastern Symposium on System Theory (SSST 2010), Mar. 2010, pp. 286-289, DOI: $10.1109 /$ SSST.2010.5442823.

[9] G. Upton and I. Cook, A Dictionary of Statistics, 2nd ed. Oxford University Press, 2008.

[10] J. Thanhofer-Pilisch, M. Vierhauser, R. Rabiser, and P. Grünbacher, "Event Capture and Compare for Runtime Monitoring of Systems of Systems," 2016, DOI: 10.1109/VACE.2016.009. 


\title{
Енергоменеджмент та виявлення подій в системі нагрівання води для забезпечення безпеки користування
}

\author{
Охмак B. M., ORCID 0000-0002-0621-3256 \\ Національний технічний університет України \\ "Київський політехнічний інститут імені Ігоря Сікорського" ROR 00syn5v21 \\ Київ, Україна
}

\begin{abstract}
Анотація-У цій статті розглядається новий метод аналізу та повідомлення про події виявлені в даних водонагрівача. В основі методу стоїть посднання декількох уже відомих методик задля забезпечення ефективної обробки даних. Ідентифікація аномальних та небезпечних подій при використанні водонагрівача важлива для забезпечення безпеки будинку та мешканців. Температура, споживання води та споживання електроенергії с основними параметрами для обробки інформації даних оповіщення. Температурні дані досліджуються на предмет перегріву, перегріву внаслідок надмірного використання, перевірясться використання електроенергії та води, чи воно є надмірним. Для аналізу та виявлення подій дані системи вимірювання в реальному часі порівнюються зі статистичними даними 3 Influxdb. Статистика 3 Influxdb формусться на основі даних що зберігаються в середовищі Influxdb, які в свою чергу змінюються внаслідок використання функції Moving Window. Статистичні дані, а саме - середнє значення та середне відхилення обчислюються для отриманих даних, та використовуються для подальшого аналізу. Порівняння даних системи вимірювання в реальному часі та Influxdb проводиться за розподілом Гаусса та застосуванням правила 3 сигм. Формусться вікно дозволених значень, межами якого с величина середнього значення +/- 3 сигма, значення що знаходяться поза межами обчисленого вікна ідентифікуються як небезпечні та ті про які необхідно повідомити користувача, для даних про споживання води та електроенергії, ліва межа вікна замінюється на нульове значення, через фізичні властивості величини та відсутності необхідності у повідомленні про низькі показники її використання. Всі спостереження та обробка інформації проведені за допомогою мови програмування Python. Дані, які виявляються як незвичайні та небезпечні, ідентифікуються як подія та зберігаються в окремому файлі. Інформація про виявлення події надсилається користувачу електронною поштою за допомогою служби Gmail де описується подія та їі можливі причини. Метод може бути використаним для різних систем побуту та індустрії.
\end{abstract}

Ключові слова - Нормальний розподіл; виявлення подій; система обігрівача; оповіщення про небезпеку; Розумний будинок; Smart house; Smart-Grid. 